\title{
Knowledge, attitude, challenges of big data analytics based on information technology staffs point of view in a developing country
}

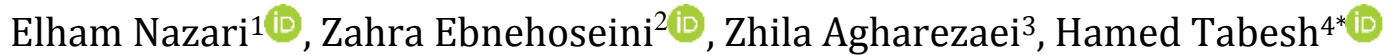 \\ ${ }^{1}$ PhD. Student of Medical Informatics, Department of Medical Informatics, Faculty of Medicine, Mashhad University of Medical Sciences, \\ Mashhad, Iran \\ ${ }^{2}$ PhD. in Medical Informatics, Psychiatry and Behavioral Sciences Research Center, Mashhad University of Medical Sciences, Mashhad, Iran \\ ${ }^{3} \mathrm{PhD}$. Student of Medical Informatics, Department of Medical Informatics, faculty of medicine, Mashhad University of Medical Sciences, \\ Mashhad, Iran \\ ${ }^{4}$ Assistant Professor, Department of Medical Informatics, Faculty of Medicine, Mashhad University of Medical Sciences, Mashhad, Iran
}

\begin{tabular}{|c|c|}
\hline Article Info & A B S T R A C T \\
\hline $\begin{array}{l}\text { Article type: } \\
\text { Research }\end{array}$ & $\begin{array}{l}\text { Introduction: The skilled IT staff about big data analytics can motivate } \\
\text { organizations to adopt the big data analytics. The aim of the current study is } \\
\text { to present the knowledge, attitude, and challenges of the big data analytics }\end{array}$ \\
\hline Article History: & ed on IT staffs' viewpoints in a developing country. \\
\hline Received: 2020-06-25 & Material and Methods: A self-administered semi-structured questionnaire \\
\hline $\begin{array}{l}\text { Accepted: 2020-07-04 } \\
\text { Published: 2020-07-05 }\end{array}$ & $\begin{array}{l}\text { was developed based on a literature review. Content validity and face } \\
\text { validity were measured using Delphi technique. The questionnaire }\end{array}$ \\
\hline *Corresponding & comprised of three parts including knowledge, attitude, a \\
\hline Hamed Tabesh & $\begin{array}{l}\text { Descriptive statistics were used to summarize the results. The chi-square } \\
\text { test was applied to identify associations between knowledge and attitude of }\end{array}$ \\
\hline $\begin{array}{l}\text { Assistant Professor, Department of } \\
\text { Medical Informatics, Faculty of }\end{array}$ & participants with the demographic characteristics. \\
\hline $\begin{array}{l}\text { Medicine, Mashhad University of } \\
\text { Medical Sciences, Mashhad, Iran }\end{array}$ & $\begin{array}{l}\text { Results: Out of a total of } 250 \text { IT staffs, } 120 \text { participated in the study. } \\
\text { Knowledge levels were low, moderate, and high in } 35.0 \%, 33.3 \% \text {, and } 31.7\end{array}$ \\
\hline Email: TabeshH@mums.ac.ir & $\begin{array}{l}\% \text { of the participants, respectively. The two most affecting factors on the } \\
\text { knowledge level of participants were age groups and sex. IT staffs hold a } \\
\text { positive attitude toward big data analytics. The most of IT staffs believed that }\end{array}$ \\
\hline $\begin{array}{l}\text { Keywords: } \\
\text { Big Data } \\
\text { Big Data Analytics } \\
\text { Attitude }\end{array}$ & $\begin{array}{l}\text { big data management is necessary for the country and they agreed that big } \\
\text { data analyzes can provide many advantages to organization managers. As } \\
\text { well, } 35 \text { challenges of the big data analytics were identified. }\end{array}$ \\
\hline $\begin{array}{l}\text { Challenges } \\
\text { Analyzes }\end{array}$ & $\begin{array}{l}\text { Conclusion: The results showed that the big data analytics face with many } \\
\text { problems in following issues: awareness and education, recruiting skilled } \\
\text { specialists, presentation big data analytics benefits to IT managers and } \\
\text { policy-makers, conducting research projects, developing a strategic plan at } \\
\text { national and local levels. }\end{array}$ \\
\hline
\end{tabular}

Cite this paper as:

Nazari E, Ebnehoseini Z, Agharezaei Z, Tabesh H. Knowledge, Attitude, Challenges of Big Data Analytics Based on Information Technology Staffs Point of View in a Developing Country. Front Health Inform. 2020; 9: 36. DOI: 10.30699/fhi.v9i1.225

\section{INTRODUCTION}

For the past 20 years, growth of the Internet and the various technologies make it appear that the world is witnessing the generation a massive amount of data in all industries. At this point, predicted data production will be 10 times greater than the current level over the coming decades $[\underline{1}, \underline{2}]$. Big data refers to "large, diverse, complex, longitudinal, and distributed datasets generated from instruments, sensors, Internet transactions, email, video, click streams, and all other digital sources available today and in the future." []ㅡ. Big data is too big data to be handled and analyzed by traditional database software tools and traditional analytic methods [4]. As well, the amount, variety, and speed of data increases, uncertainty inherent within big data, leading to a lack of confidence in the resulting traditional analytic methods and it has become almost impossible to process the big data with the existing methods. Advanced data analysis methods can be used to handle and analyze these data []ㅡ.

The methods used to analyze big data are known as "big data analytics" that refers to "the process of analyzing a large number of datasets to explore patterns, unidentified correlations, market trends, users preferences, and other valuable information 
that previously could not be analyzed and handed with traditional tools" [్]. Big data analytics encompass many benefits such as reducing cost, improving quality of services, reducing errors, providing highly accurate models, discovering useful data patterns, improving data quality, facilitating data interpretation, exploring important features, and summarizing and sharing data for critical decisions making $[\underline{2}, \underline{6}-\underline{10}]$. Big data analytics were used in a diverse range of fields. Some of them included the banking industry, medical care, education, insurance, transportation, ambulance monitoring, traffic management, and appointment scheduling management [11-15].

Though the benefits of big data analytics are factual and considerable, it remains a number of challenges that must be addressed to fully realize the potential of big data advantages. Many countries including, developing countries are still far behind in the big data analytics [16]. However, organizations attempting to deploy big data analytics face numerous obstacles, including a lack of specialists with data management and analysis skills for big data. Even, they face fundamental barriers such as inadequate technological infrastructure and lack of financial resource. These issues led to the field of big data analytics grow slowly [17-20] and be in earlystage in various industries. Despite the important role of big data analytics as a powerful source of value for all industries, big data remains a fashionable but not well understood or fully clarified concept [21].

Since the spread of Internet and IT technologies in organizations' developing countries and big data analytics are in early-stage in these countries, the skilled IT staff about big data analytics can motivate organizations to consider the advantage of this field. As well, conducting an empirical study for investigating the IT staffs' knowledge level and attitude toward the big data analytics can provide scientific evidence. Hence, to assess the attitude and knowledge of IT staffs and understanding the challenges of implementation of big data analytics is the focus of this paper. The aim of the present study is to evaluate the knowledge level, attitude, and challenges of the big data analytics based on IT staff' viewpoints in Mashhad which is the second-most populous city in Iran as a developing country.

\section{MATERIAL AND METHODS}

\section{Study location}

This cross-sectional study was conducted on IT staffs who worked in various organizations in Mashhad, Iran. Mashhad is the largest city in the eastern of Iran with about 3 million people, located on the border with Afghanistan and Turkmenistan, there are 70 public organizations and private organizations in Mashhad.

\section{Instrument}

A self-administered semi-structured questionnaire was formed based on a literature review in google scholar, science direct, and EMBASE databases to collect data. An expert panel with expertise in medical informatics, biostatistics, health information management, and computer science was recruited as content experts. Two Delphi rounds were performed by 11 experts to ensure content validity and face validity of the questionnaire.

The final version of the questionnaire comprised of 27 questions that covered three sections including knowledge, attitude, and challenges about the big data analytics based in IT staff point of view. The sections and questions of the questionnaire are shown in Table 1.

The knowledge section encompassed 10 multiplechoice questions. There were four possible answers to each question, of which one was correct. Participants were requested to respond to each of the questions. A correctly answered question was scored 1 and an incorrectly answered question was scored 0 . The knowledge's score was the sum of the correctly answered questions. The knowledge's score was categorized as follows: 1- Low (0-3), 2- Moderate (45 scores), and 3- High (6-10).

The attitude section consisted of 10 closed-ended questions on a 6-Likert scale range from 1 to 6 and 3 multiple-choice questions. In this section, the rang of completely agree, mostly agree, and slightly agree were consider as "positive attitude" and the rang of slightly disagree, mostly disagree, and completely disagree were consider as "negative attitude".

Challenges section had 3 multiple-choice questions and one open-ended question. In an open-ended question, patricians could express the challenges of big data analytics in the country. Identified challenges of big data analytics were extracted and categorized independently by two researchers. The results were saved in excel files. Then, two excel files were combined in expert panel meetings that were held by two researchers. Unresolved disagreements were discussed with a third researcher. The instrument was validated by an expert panel with CVI: 0.92 and CVR: 0.89 . The overall Cronbach's alpha value of the instrument was determined as 0.81 , representing high reliability.

\section{Participants}

All public and private organizations were in Mashhad and had an IT unit, were included in the current study. The empirical data were collected from IT staffs with experience in using various software who worked in the included organizations. The researches met all IT staffs in person and invited them to participate in the study. Questionnaires were provided to IT staffs who agreed to participate in the 
study.

\section{Data analysis}

The IBM SPSS version 21 was used to analyze the data. Statistical significance for all of the analysis was defined as $\mathrm{p} \leq 0.05$. Data screening was performed for missing data. Missing data were excluded from the analysis. Descriptive statistics were used to summarize the demographic characteristics of the IT staffs, knowledge level, attitude and, challenges. Chisquare test and t-test were used to compare the differences in knowledge and attitude within the demographic characteristics. As well, the relationship between the knowledge levels and the attitude were assessed by Chi-square test.

Table 1: Questionnaire sections and questions

\begin{tabular}{|c|c|c|}
\hline Sections & Questions & Response scale \\
\hline \multirow{10}{*}{ Knowledge } & What is the definition of big data analytics? & Multiple-choice \\
\hline & What is the focus of big data analytics? & Multiple-choice \\
\hline & What are the advantages of big data analytics? & Multiple-choice \\
\hline & What are the disadvantages of big data analytics? & Multiple-choice \\
\hline & What are the big data resources? & Multiple-choice \\
\hline & What is the most important necessity of big data analytics? & Multiple-choice \\
\hline & What item is not characteristic of big data? & Multiple-choice \\
\hline & What is the last phase of big data analytics? & Multiple-choice \\
\hline & Which of the following items is true about big data analytics? & Multiple-choice \\
\hline & Which items is not one of the applications of big data analytics? & Multiple-choice \\
\hline \multirow{13}{*}{ Attitude } & How much do you agree with the necessity of big data management in the country? & 5-Likert scale \\
\hline & $\begin{array}{l}\text { How much do you think that to recruit a specialist with expertise in big data analytics } \\
\text { is necessary for your organization? }\end{array}$ & 5-Likert scale \\
\hline & $\begin{array}{l}\text { How much do you think that using big data analytics has many advantages for } \\
\text { organization managers? }\end{array}$ & 5-Likert scale \\
\hline & $\begin{array}{l}\text { How much do you think using big data analytics can increase workload in your } \\
\text { organization? }\end{array}$ & 5-Likert scale \\
\hline & $\begin{array}{l}\text { How much do you think holding the in-person training courses about big data } \\
\text { analytics can increase the application of big data analytics in your organization? }\end{array}$ & 5-Likert scale \\
\hline & How much you feel IT managers do not resist the adoption of big data analytics? & 5-Likert scale \\
\hline & $\begin{array}{l}\text { How much do you think IT staffs can improve their big data analytics skills using the } \\
\text { current education materials in Persians books? }\end{array}$ & 5-Likert scale \\
\hline & $\begin{array}{l}\text { How much do you think IT staffs can improve their big data analytics skills with using } \\
\text { educational websites? }\end{array}$ & 5-Likert scale \\
\hline & $\begin{array}{l}\text { Do How much do you think the Iranian specialist can hold effective big data analytics } \\
\text { courses? }\end{array}$ & 5-Likert scale \\
\hline & $\begin{array}{l}\text { Do How much do you think to recruit foreign specialists is a good idea for training big } \\
\text { data analytics? }\end{array}$ & 5-Likert scale \\
\hline & $\begin{array}{l}\text { In your opinion, how the percentage of IT staffs have big data analytics skills in the } \\
\text { country? }\end{array}$ & Multiple-choice \\
\hline & In your opinion, in which fields we encounter more big data compared to the others? & Multiple-choice \\
\hline & Which one of the tools would you prefer for big data analytics? & Multiple-choice \\
\hline \multirow{4}{*}{$\begin{array}{l}\text { Barriers } \\
\text { and } \\
\text { challenges }\end{array}$} & $\begin{array}{l}\text { In your opinion, how we can motivate IT managers to use big data analytics on their } \\
\text { organizations? }\end{array}$ & Multiple-choice \\
\hline & In your opinion, why is the application of big data analytics so low in the country? & Multiple-choice \\
\hline & $\begin{array}{l}\text { In your opinion, how many years later Iran would reach the level of developed } \\
\text { countries in the field of big data analytics? }\end{array}$ & Multiple-choice \\
\hline & $\begin{array}{l}\text { In your opinion, what are the challenges and barriers of the application of big data } \\
\text { analytics the country? }\end{array}$ & $\begin{array}{l}\text { open-ended } \\
\text { question }\end{array}$ \\
\hline
\end{tabular}

\section{RESULTS}

\section{Participants}

Out of a total of 70 public organizations and private organizations in Mashhad, 48 were included in the present study. Some of the included organizations were social security insurance, hospitals, transportation organization, and governorate. The researchers met with 250 targets IT staffs, among which 123 individuals agreed to participate in the study and finally, 120 valid questionnaires were analyzed. Table 2 demonstrates the characteristics of the participants. Over two-thirds of the participants were men. The age range of users was 20 to 64 years, and most of the participants were aged 25-34. The majority of participants were computer specialists and $69 \%$ of all participants had more than 6 years of work experience. The majority of the participants had 
a Bachelor's and a Master's degree (94\%).

Table 2: Individual characteristics of the participants in this study $(n=120)$

\begin{tabular}{|c|c|c|}
\hline Characteristics & Sub groups & $\begin{array}{c}\text { Frequency } \\
(\%)\end{array}$ \\
\hline \multirow{5}{*}{ Age } & 18-24 year & $19(15.4)$ \\
\hline & 25-34 year & $61(49.6)$ \\
\hline & 35-44 year & $36(29.3)$ \\
\hline & 45-54 year & $6(4.9)$ \\
\hline & 55-64 year & $1(0.8)$ \\
\hline \multirow{2}{*}{ Sex } & Male & $80(65.6)$ \\
\hline & Female & $40(32.5)$ \\
\hline \multirow{4}{*}{$\begin{array}{l}\text { Work experience } \\
\text { (years) }\end{array}$} & $<1$ & $27(22.5)$ \\
\hline & 1-5 year & $24(20.0)$ \\
\hline & 5-10 year & $35(29.2)$ \\
\hline & $>10$ & $34(28.3)$ \\
\hline \multirow{6}{*}{ Discipline } & Computer science & $77(64.2)$ \\
\hline & Information technology & $23(19.2)$ \\
\hline & $\begin{array}{c}\text { Telecommunications } \\
\text { (Electricity) }\end{array}$ & $12(10.0)$ \\
\hline & Accountancy & $3(2.5)$ \\
\hline & Medical informatics & $1(0.8)$ \\
\hline & $\begin{array}{c}\text { Health information } \\
\text { system }\end{array}$ & $2(1.7)$ \\
\hline \multirow{4}{*}{ Education level } & Bachelor's & $60(50)$ \\
\hline & Master's & $53(44.2)$ \\
\hline & General practitioner & $4(3.3)$ \\
\hline & $\mathrm{PhD}$ & $2(1.7)$ \\
\hline \multirow{4}{*}{$\begin{array}{l}\text { Average number } \\
\text { of scientific study } \\
\text { hours per week }\end{array}$} & $<1$ hour & $17(14.2)$ \\
\hline & 1-3 hour & $34(28.3)$ \\
\hline & 3-4 hour & $19(15.8)$ \\
\hline & $>5$ hour & $49(40.8)$ \\
\hline \multirow{4}{*}{$\begin{array}{l}\text { Average number } \\
\text { of nonscientific } \\
\text { study hours per } \\
\text { week }\end{array}$} & $<1$ hour & $31(25.8)$ \\
\hline & 1-3 hour & $45(37.5)$ \\
\hline & 3-4 hour & $22(18.3)$ \\
\hline & $>5$ hour & $20(16.7)$ \\
\hline
\end{tabular}

IT staffs' knowledge level about big data analytics

Table 3 shows the knowledge levels of participants in big data analytics. Knowledge levels were low, moderate, and high in 35.0\%, 33.3\%, and $31.7 \%$ of the participants, respectively. The knowledge s' score most of the participants were from scores of 3 to 5 . Results (Table 4) of chi-square tests showed that the two factors most affecting the knowledge level of participants were age groups $(p=0.040$, Chi-square value $=13.167)$ and sex $(p=0.009$, Chi-Square value=9.445). A significantly higher level of knowledge was observed in the age group of 25-34 years. There was no significant difference between the knowledge level and other users' characteristics including work experience, discipline, education level, the average number of scientific study hours per week, and, the average number of nonscientific study hours per week.

Table 3: IT staffs' knowledge level of big data analytics

\begin{tabular}{|c|c|c|}
\hline Category & Score & Frequency \% \\
\hline \multirow{4}{*}{ Low } & 0 & $4(3.3)$ \\
\cline { 2 - 3 } & 1 & $4(3.3)$ \\
\cline { 2 - 3 } & 2 & $11(9.2)$ \\
\cline { 2 - 3 } & 3 & $23(19.2)$ \\
\hline \multirow{3}{*}{ Moderate } & 4 & $22(18.3)$ \\
\cline { 2 - 3 } & 5 & $18(15.0)$ \\
\hline \multirow{3}{*}{ High } & 6 & $16(13.3)$ \\
\cline { 2 - 3 } & 7 & $14(11.7)$ \\
\cline { 2 - 3 } & 8 & $5(4.2)$ \\
\hline Total & 9 & $3(2.5)$ \\
\hline
\end{tabular}

Table 4: The participants' knowledge level in the age and sex groups

\begin{tabular}{|c|c|c|c|c|c|}
\hline \multirow{2}{*}{ 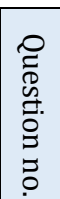 } & \multirow{2}{*}{ 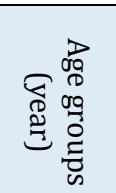 } & \multicolumn{3}{|c|}{ Knowledge levels } & \multirow[b]{2}{*}{$\begin{array}{l}\text { Total } \\
(\mathrm{n}, \%)\end{array}$} \\
\hline & & $\begin{array}{c}\text { Low } \\
(n, \%)\end{array}$ & $\begin{array}{c}\text { Moderate } \\
(\mathrm{n}, \%)\end{array}$ & $\begin{array}{l}\text { High } \\
(n, \%)\end{array}$ & \\
\hline \multirow{5}{*}{ 完 } & $18-24$ & $\begin{array}{c}13 \\
(30.2)\end{array}$ & $4(9.8)$ & $\begin{array}{c}2 \\
(5.1)\end{array}$ & $\begin{array}{c}19 \\
(15.4)\end{array}$ \\
\hline & $25-34$ & $\begin{array}{c}18 \\
(41.9)\end{array}$ & $22(53.7)$ & $\begin{array}{c}21 \\
(53.8)\end{array}$ & $\begin{array}{c}61 \\
(49.6)\end{array}$ \\
\hline & $35-44$ & $\begin{array}{c}9 \\
(20.9)\end{array}$ & $14(34.1)$ & $\begin{array}{c}13 \\
(33.3)\end{array}$ & $\begin{array}{c}36 \\
(29.3)\end{array}$ \\
\hline & $45-54$ & $\begin{array}{c}3 \\
(7.0)\end{array}$ & $1(2.4)$ & $\begin{array}{c}3 \\
(7.7)\end{array}$ & $\begin{array}{c}7 \\
(5.7)\end{array}$ \\
\hline & Total & $\begin{array}{c}43 \\
(100)\end{array}$ & $41(100)$ & $\begin{array}{c}39 \\
(100)\end{array}$ & $\begin{array}{c}123 \\
(100)\end{array}$ \\
\hline \multirow{3}{*}{ 完 } & Male & $\begin{array}{c}31 \\
(73.8)\end{array}$ & $31(77.5)$ & $\begin{array}{c}18 \\
(47.4)\end{array}$ & $\begin{array}{c}80 \\
(66.7)\end{array}$ \\
\hline & Female & $\begin{array}{c}11 \\
(26.2)\end{array}$ & $9(22.5)$ & $\begin{array}{c}20 \\
(52.6)\end{array}$ & $\begin{array}{c}40 \\
(33.3)\end{array}$ \\
\hline & Total & $\begin{array}{c}42 \\
(100)\end{array}$ & $40(100)$ & $\begin{array}{c}38 \\
(100)\end{array}$ & $\begin{array}{c}120 \\
(100)\end{array}$ \\
\hline
\end{tabular}

IT staffs' attitude toward the big data analytic

\section{IT staffs' attitude toward the big data analytics in Likert-Scale questions}

93.4\% $(n=112)$ of the participants believed that big data management is necessary for the country. Around $74.2 \%(n=89)$ of the participants agreed that big data analyzes can provide many advantages to organization managers. As well, $98.3 \%,(n=18)$ of the participants feel that IT managers do not resist the adoption of big data analytics. $74.2 \%(n=89)$ of the participants think that to recruit a specialist with expertise in big data analytics is necessary for their organization. Out of all participants, $91.9 \%(n=110)$ and $64.2 \%(n=77)$ believed that they cannot improve their big data analytics skills using the current education materials in Persians books; online courses and educational websites, receptively. And also, $60.8 \%(n=73)$ believed that the Iranian specialist 
cannot hold effective big data analytics courses. $62.5 \%(n=75)$ of the participants agreed that holding the in-person training courses about big data analytics can increase the application of big data analytics in their organization. Table 5 draws IT staffs' attitude toward big data analytics in LikertScale questions.

Table 5: Participant' attitudes toward the big data analytics in Likert-Scale questions

\begin{tabular}{|c|c|c|}
\hline Questions & $\begin{array}{l}\text { Negative } \\
\text { attitude } \\
(\%)\end{array}$ & $\begin{array}{l}\text { Positive } \\
\text { attitude } \\
(\%)\end{array}$ \\
\hline $\begin{array}{l}\text { How much do you agree with the } \\
\text { necessity of big data management } \\
\text { in the country? }\end{array}$ & $8(6.7)$ & $\begin{array}{c}112 \\
(93.3)\end{array}$ \\
\hline $\begin{array}{l}\text { How much do you think that to } \\
\text { recruit a specialist with expertise } \\
\text { in big data analytics is necessary } \\
\text { for your organization? }\end{array}$ & 35 (29.2) & $\begin{array}{c}85 \\
(70.8)\end{array}$ \\
\hline $\begin{array}{l}\text { How much do you think that using } \\
\text { big data analytics has many } \\
\text { advantages for organization } \\
\text { managers? }\end{array}$ & 31 (25.8) & $\begin{array}{c}89 \\
(74.2)\end{array}$ \\
\hline $\begin{array}{l}\text { How much do you think using big } \\
\text { data analytics can increase } \\
\text { workload in your organization? }\end{array}$ & $60(50.0)$ & $\begin{array}{c}60 \\
(50.0)\end{array}$ \\
\hline $\begin{array}{l}\text { How much do you think holding } \\
\text { the in-person training courses } \\
\text { about big data analytics can } \\
\text { increase the application of big } \\
\text { data analytics in your } \\
\text { organization? }\end{array}$ & 45 (37.5) & $\begin{array}{c}75 \\
(62.5)\end{array}$ \\
\hline $\begin{array}{l}\text { How much do you feel IT } \\
\text { managers do not resist the } \\
\text { adoption of big data analytics? }\end{array}$ & 21 (1.7) & $\begin{array}{c}118 \\
(98.3)\end{array}$ \\
\hline $\begin{array}{l}\text { How much do you think IT staffs } \\
\text { can improve their big data } \\
\text { analytics skills using the current } \\
\text { education materials in Persians } \\
\text { books? }\end{array}$ & $\begin{array}{c}110 \\
(91.7)\end{array}$ & $10(8.3)$ \\
\hline $\begin{array}{l}\text { How much do you think IT staffs } \\
\text { can improve their big data } \\
\text { analytics skills with using } \\
\text { educational websites? }\end{array}$ & 77 (64.2) & $\begin{array}{c}43 \\
(35.8)\end{array}$ \\
\hline $\begin{array}{l}\text { Do How much do you think the } \\
\text { Iranian specialist can hold } \\
\text { effective big data analytics } \\
\text { courses? }\end{array}$ & $73(60.8)$ & $\begin{array}{c}47 \\
(39.2)\end{array}$ \\
\hline $\begin{array}{l}\text { Do How much do you think to } \\
\text { recruit foreign specialists is a } \\
\text { good idea for training big data } \\
\text { analytics? }\end{array}$ & $57(47.5)$ & $\begin{array}{c}63 \\
(52.5)\end{array}$ \\
\hline
\end{tabular}

\section{IT staffs' attitude toward the big data analytics in multiple-choice questions}

As shown in Table 5, 50\% $(n=60)$ of the participant believed that less than $10 \%$ of IT staffs have big data analytics skills. On participants' point of view, three fields including 'financial and insurance activities"; "professional, scientific, and technical activities "; and "administrative activities"; and support services were faced with more big data, respectively.

Table 6 showed IT staffs' attitude toward big data analytics. Most of the participants prefer to use from "Spark" and "R" software for big data analytics. As well, the results showed $26.7 \% \quad(n=32)$ of the participants believed that only one software could be used for big data analytics, 46.7\% ( $n=56)$ selected two software, $17.5 \%$ (21) selected three software, and $9.2 \%(n=11)$ selected more than three software (Table 6).

Table 6: Participant' attitudes toward the big data analytics in multiple-choice questions

\begin{tabular}{|c|c|}
\hline Questions & Items (n, \%) \\
\hline $\begin{array}{l}\text { In your opinion, how } \\
\text { percentage of the IT staffs } \\
\text { have big data analytics } \\
\text { skills in the country? }\end{array}$ & $\begin{array}{l}x<10 \%(60,50) \\
10 \% \leq x<30 \%(36,30) \\
30 \% \leq x<50 \%(20,17) \\
50 \% \leq x(4,3)\end{array}$ \\
\hline $\begin{array}{l}\text { In your opinion, in which } \\
\text { fields we encounter more } \\
\text { big data compared to the } \\
\text { others? }\end{array}$ & $\begin{array}{l}\text { Agriculture, forestry, } \\
\text { fishing }(6,0.5) \\
\text { Industry and mining } \\
(16,13.3) \\
\text { Information and } \\
\text { communication }(14,11.7) \\
\text { Energy supply and its } \\
\text { consumption management } \\
\text { (9,7.5) } \\
\text { Transportation and } \\
\text { warehousing }(0,0) \\
\text { Education }(11,9.2) \\
\text { Professional, scientific, } \\
\text { and technical activities } \\
(24,20) \\
\text { Financial and insurance } \\
\text { activities }(36,30) \\
\text { Administrative activities } \\
\text { and support services } \\
(17,14.2) \\
\text { Activities related to } \\
\text { human health and social } \\
\text { assistance }(6,5) \\
\text { Other cases }(61,50.8) \\
\end{array}$ \\
\hline $\begin{array}{l}\text { Which one of the tools } \\
\text { would you prefer for big } \\
\text { data analytics? }\end{array}$ & $\begin{array}{l}\text { R }(33,27.5) \\
\text { Matlab }(19,15.8) \\
\text { Python }(6,5.5) \\
\text { Hadoop }(29,24.2) \\
\text { Spark }(41,34.2) \\
\text { F-link }(8,6.7) \\
\text { SPSS Modeler }(6,5.0) \\
\text { Weka }(27,22.5) \\
\text { Rapid minder }(1,0.8) \\
\text { SQL }(5,4.2)\end{array}$ \\
\hline
\end{tabular}

The relation between knowledge levels and attitude in the IT staffs

The results of assessing relations between the knowledge level and attitudes toward big data analytics are shown in Table 7 . The results showed that there was a statistically significant difference between the positive attitude toward the necessity of big data management in the country (QP1) and 
knowledge level. As well, the same difference observed between the increasing workload in the organizations due to the application of big data analytics and knowledge level (QP9) (Table 7). Participants with a higher knowledge level believed that the application of big data analytics can increase workload (QP9) (Table 7). Table 8 shows the significant difference between the participants' knowledge levels and attitude.

Table 7: The relation between participants' knowledge levels and attitude in all attitude questions

\begin{tabular}{|c|c|c|}
\hline Questions & Chi-Square value & $\mathrm{P}$-value \\
\hline QP1 a & 22.046 & .005 \\
\hline QP2 b & 10.584 & .230 \\
\hline QP3 b & 5.737 & .22 \\
\hline QP4 b & .721 & .949 \\
\hline QP5 b & .54 & .973 \\
\hline QP6b & 5.871 & .438 \\
\hline QP7b & 4.418 & .11 \\
\hline $\mathrm{QP8}^{\mathrm{b}}$ & 1.295 & .523 \\
\hline QP9 a & 8.346 & .015 \\
\hline QP10b & 1.356 & .508 \\
\hline QP11b & 4.056 & .398 \\
\hline QP12b & 2.197 & .901 \\
\hline QP13 b & 2.376 & .667 \\
\hline QP14b & 1.901 & 0.754 \\
\hline QP15b & 3.953 & .412 \\
\hline QP16b & 6.649 & .156 \\
\hline \multicolumn{3}{|c|}{$\begin{array}{l}\text { Note: The significant results within each group of users are indicated by } \\
\text { letters } a \text { and } b \text {,values not sharing a common letter differ significantly ( } \\
<0.05)\end{array}$} \\
\hline
\end{tabular}

\section{The challenges of big data analytics}

The results showed about two thirds (68.3\%) of the participants believed that more than 5 years later Iran would reach the level of developed countries in the field of big data analytics.

On the participants' point of view, the most important motivation for using bid data analytics by IT managers was training and workshop, encouragement, coercion, and advertising, receptively. As well, 39.2\% $(n=47)$ of the participants believed that the most important reason for low the application of big data analytics was the complex analysis of this type of data. Absent of bid data in the country, lack of skilled specialists, and expensive equipment were other reasons, receptively. Table 9 shows the results of open-end questions about the facilitators and barriers of big data analytics based on IT staffs' point of view.

Out of a total of 120 participants, 53 responded to the open-ended question. 35 challenges were identified of the big data analytics which covered 12 groups. these groups were as follows: lack of knowledge and attitude of managers and policymakers, lack government policies and plans, lack of knowledge and attitude of IT managers, lack of educational resources and courses, low data quality, weakness in data management, dispersion of information and lack of an aggregation standardized, lack of expert staff, inadequate equipment, lack of successful implemented big data analytics projects, cost, and shortage and inadequate research (Table 10).

Table 8: The significant difference between the participants' knowledge levels and attitude

\begin{tabular}{|c|l|c|c|c|c|}
\hline \multirow{2}{*}{ Attitude groups } & \multicolumn{3}{|c|}{ Knowledge levels } & \multirow{2}{*}{ Total } \\
\cline { 3 - 6 } \multicolumn{2}{|c|}{} & $\begin{array}{c}\text { Low } \\
(\%)\end{array}$ & $\begin{array}{c}\text { Moderate } \\
(\%)\end{array}$ & $\begin{array}{c}\text { High } \\
(\%)\end{array}$ & \\
\hline \multirow{4}{*}{ QP1 } & $\begin{array}{l}\text { Positive } \\
\text { attitude }\end{array}$ & $\begin{array}{c}36 \\
(83.7)\end{array}$ & $40(97.6)$ & $\begin{array}{c}39 \\
(100)\end{array}$ & $\begin{array}{c}115 \\
(93.0)\end{array}$ \\
\cline { 2 - 6 } & $\begin{array}{l}\text { Negative } \\
\text { attitude }\end{array}$ & $\begin{array}{c}7 \\
(16.3)\end{array}$ & $1(2.4)$ & $0(0)$ & $\begin{array}{c}8 \\
(6.5)\end{array}$ \\
\hline \multirow{2}{*}{ Total } & $\begin{array}{c}43 \\
(100)\end{array}$ & $41(100)$ & $\begin{array}{c}39 \\
(100)\end{array}$ & $\begin{array}{c}123 \\
(100)\end{array}$ \\
\hline \multirow{4}{*}{ QP9 } & $\begin{array}{l}\text { Positive } \\
\text { attitude }\end{array}$ & $\begin{array}{c}17 \\
(47.2)\end{array}$ & $29(75.5)$ & $\begin{array}{c}16 \\
(42.1)\end{array}$ & $\begin{array}{c}62 \\
(54.4)\end{array}$ \\
\cline { 2 - 6 } & $\begin{array}{l}\text { Negative } \\
\text { attitude }\end{array}$ & $\begin{array}{c}19 \\
(52.8)\end{array}$ & $11(27.5)$ & $\begin{array}{c}22 \\
(57.9)\end{array}$ & $\begin{array}{c}52 \\
(45.6)\end{array}$ \\
\hline \multirow{2}{*}{ Total } & & $\begin{array}{c}36 \\
(100)\end{array}$ & $40(100)$ & $\begin{array}{c}38 \\
(100)\end{array}$ & $\begin{array}{c}114 \\
(100)\end{array}$ \\
\hline
\end{tabular}

\section{DISCUSSION}

In the current study, a questioner was proposed to evaluate knowledge, attitude, and challenges of big data analytics based on the IT staffs' point of view. It was found to have a high rate of validity and reliability. This can be in future studies. As well, the association between the knowledge level, attitude toward big data analytics, and users' characteristics such as age, gender, and education level were investigated. The present study was conducted in one of the largest cities in Iran. The results of the present study highlight the characteristics and opinions IT staffs about big data analytics in a developing country. The most important findings of the study will be discussed in following paragraphs.

The perceptions of the Health Informatics Scientists about big data technology in Healthcare were evaluated in the study by Minou et al. Based on their findings, $86.7 \%$ of scientists had knowledge of big data. As well, $100 \%$ of the participants believed that big data technology can be implemented in Healthcare [22]. Our results releveled that knowledge level in most of the participants was low or moderate. It was lower than the knowledge level reported in the study by Minou et al. [22]. And also, our findings indicated that just $5 \%$ of participant believed health care face with big data. Results of this showed that there was a significant difference between age group and knowledge level. A significantly higher level of knowledge was observed in the age group of 25-34 years. Given that this age group is considered the young workforce in the organizations. It seems to learn of big data analytics coming to a change. 
Table 9: Barriers of the big data analytics based on IT staffs' point of view

\begin{tabular}{|l|l|}
\hline \multicolumn{1}{|c|}{ Questions } & \multicolumn{1}{|c|}{ Items (n, \%) } \\
\hline $\begin{array}{l}\text { In your opinion, how many years later Iran would } \\
\text { reach the level of developed countries in the field of } \\
\text { big data analytics? }\end{array}$ & $\begin{array}{l}\text { 1 year later }(2,1.7) \\
\text { 2-3 years later }(7,5.8) \\
\text { 4-5 years later }(20,16.7) \\
\text { More than 5 years later }(82,68.3)\end{array}$ \\
\hline $\begin{array}{l}\text { In your opinion, how we can motivate IT managers } \\
\text { to use big data analytics on their organizations? }\end{array}$ & $\begin{array}{l}\text { Training and workshop }(64,53.3) \\
\text { Advertising }(10,8.3) \\
\text { Coercion }(13,10.8)\end{array}$ \\
Encouragement $(35,29.2)$
\end{tabular}

Table 10: Challenges of the big data analytics based on IT staffs' point of view

\begin{tabular}{|c|c|}
\hline Category & Items \\
\hline $\begin{array}{l}\text { 1-Lack of knowledge and } \\
\text { attitude of managers and } \\
\text { policymakers }\end{array}$ & $\begin{array}{l}\text { 1-Lack of general awareness in organizations about big data analytics. } \\
\text { 2-Low level of knowledge about big data analytics among organization managers and policy- } \\
\text { makers. } \\
\text { 3-Lack of awareness about importance, values, and advantages of big data analytics among } \\
\text { organization managers and policy-makers. }\end{array}$ \\
\hline $\begin{array}{l}\text { 2-Lack government policies } \\
\text { and plans }\end{array}$ & $\begin{array}{l}\text { 4- Lack of priority of big data analytics implementation in strategies and plans. } \\
\text { 5-Lack of priority of big data analytics projects implementation in private organization } \\
\text { 6-Lack of government strategic focus to implement the big data analytics project } \\
\text { 7-Lack of appropriate rules for data collection and management }\end{array}$ \\
\hline $\begin{array}{l}\text { 3-Lack of knowledge and } \\
\text { attitude of IT managers }\end{array}$ & $\begin{array}{l}\text { 8-Low level of knowledge about big data analytics among IT managers } \\
\text { 9-Lack of awareness about the importance, values, and advantages of big data analytics among } \\
\text { IT managers. } \\
\text { 10-Lack of positive attitude toward big data analytics among Iranians IT specialists. } \\
\text { 11-Lack of sufficient knowledge about the methods of big data analytics among Iranians IT } \\
\text { specialists }\end{array}$ \\
\hline $\begin{array}{l}\text { 4-Lack of educational } \\
\text { resources and courses }\end{array}$ & $\begin{array}{l}\text { 12-Lack of Persian educational resources. } \\
\text { 13-Inadequate training courses. } \\
\text { 14-Lack of skilled specialist for holding big data analytics courses Lack interest or motivation } \\
\text { in study and learning of big data analytics concepts }\end{array}$ \\
\hline 5-Low data quality & $\begin{array}{l}\text { 15-Lack of accurate, appropriate, and complete data in databases } \\
\text { 16-The presence of wrong data in databases } \\
\text { 17-The low-quality data in databases }\end{array}$ \\
\hline $\begin{array}{l}\text { 6-Weakness in data } \\
\text { management }\end{array}$ & $\begin{array}{l}\text { 18-Inadequate data management methods. } \\
\text { 19-Not existing data warehouse. } \\
\text { 20-Do not explore patterns and relationships between data. }\end{array}$ \\
\hline $\begin{array}{l}\text { 7-Dispersion of information } \\
\text { and lack of an aggregation } \\
\text { standardized }\end{array}$ & $\begin{array}{l}\text { 21-Non-interoperable software and tools for data gathering } \\
\text { 22-Inadequate standards for data aggregation. } \\
\text { 23-Dispersion of data and information in the country. }\end{array}$ \\
\hline 8-Lack of expert staff & $\begin{array}{l}\text { 24-Lack of big data analytics specialists in the country. } \\
\text { 25-Do not recruit current specialists of big data analytics in the organizations. } \\
\text { Lack of practical experience big data analytics by current specialists. }\end{array}$ \\
\hline 9-Inadequate equipment & $\begin{array}{l}\text { 26-Lack of proper infrastructure hardware and network. } \\
\text { 27-Lack of big data analytics software. }\end{array}$ \\
\hline $\begin{array}{l}\text { 10-Lack of successful } \\
\text { implemented big data } \\
\text { analytics projects }\end{array}$ & $\begin{array}{l}\text { 28-Failure of big data analytics projects. } \\
\text { 29-Lack of successful big data analytics projects. }\end{array}$ \\
\hline 11-Cost & 30-High costs the application of big data analytics. \\
\hline $\begin{array}{l}\text { 12- Shortage inadequate } \\
\text { research }\end{array}$ & $\begin{array}{l}\text { 31-Lack of enough research about big data analytics. } \\
\text { 32-Conducting studied about big data analytics in the small and local level. } \\
\text { 33-Lack of large-scale, comprehensive projects of big data analytics. } \\
\text { 34-Conducting studied about big data analytics by non-skilled specialists. }\end{array}$ \\
\hline
\end{tabular}


Evaluation knowledge level of specialists about big may help to understand their attitudes and behaviors [23]. The results of the current study support this finding. There was a statistically significant difference between the positive attitude toward the necessity of big data management and knowledge level. The participant acquired higher levels of knowledge considered big data analytics is essential.

Accordingly, those who had high knowledge believed that Big Data analyzes impose workload on authorities. It seems that these people are aware of the wide range of services in the Big Data area and the development of various methods and platforms, and it is thought that learning this field would lead to the increased responsibilities and workload.

The results of the study revealed that IT staffs hold a positive attitude toward big data analytics. Most of IT staffs believed that big data management is necessary for the country and they agreed that big data analyzes can provide many advantages to organization managers. But, they believed that the application of big data analytics faced a number of challenges such as lack of education materials in Persians books, lack of skilled specialists, and lack of effective training course.

The results showed that some identified challenges in the current study were common with developed countries. But, there was a number of different challenges. A short explanation of the findings was presented in the following paragraphs. An empirical investigation of challenges and risks about big data technologies in various companies were conducted by Raguseo [24]. In this study, the lack of information system and infrastructure support and minimal IT expertise was reported as big data technologies challenges. The results of the current study support this finding. As well, Raguseo points out a number of other challenges including privacy issues, security issues, capital outlay with no guarantee of likely returns, uncertainty about how to measure potential benefits, and uncertainty about how to measure the involved costs. In the present study, none of these challenges was reported. Participants declared different challenges such as shortage of skilled specialists, lack of educational material and resources, and lack of knowledge and attitude of managers. The reason for the difference between the present study and their study is possibly a shortage of the application of big data analytics in the country. Most of the IT staffs had a low knowledge level of big data. Those had high knowledge level concerned with an initial investment for starting a project and adequate infrastructure.

\section{CONCLUSION}

Our results represented that the most critical areas requiring intervention lie in the area of awareness and education, recruiting skilled specialists, presentation big data analytics benefits to IT managers and policymakers, conducting research projects, developing a strategic plan at national and local levels. It is suggested that in future studies, the knowledge, attitude, and challenges of big data analytics based on students, IT managers, and policy makers be evaluated. As well, the impacts of education course on knowledge, attitude, and their performance can be investigated.

\section{ACKNOWLEDGEMENT}

The present study is the result of research project approved by the vice chancellery for research of Mashhad University of Medical Sciences (grant number 961731).

\section{AUTHOR'S CONTRIBUTION}

EN, ZE, ZA, and HT designed the study, gathered and analyzed the data. The authors agree on this final form of the manuscript, and attested that all authors contributed in the final draft of the manuscript.

\section{CONFLICTS OF INTEREST}

The authors declare no conflicts of interest regarding the publication of this study.

\section{FINANCIAL DISCLOSURE}

The present study was conducted by support of Mashhad University of Medical Sciences (grant number 961731).

\section{REFERENCES}

1. Nambiar R, Bhardwaj R, Sethi A, Vargheese R. A look at challenges and opportunities of big data analytics in healthcare. International Conference on Big Data. IEEE; 2013.

2. Raghupathi W, Raghupathi V. Big data analytics in healthcare: promise and potential. Health Inf Sci Syst. 2014; 2(1): 3. PMID: 25825667 DOI: 10.1186/20472501-2-3 [PubMed]

3. Olayinka O, Kekeh M, Sheth-Chandra M, Akpinar-Elci
M. Big Data knowledge in global health education. Ann Glob Health. 2017; 83(3-4): 676-81. PMID: 29221544 DOI: 10.1016/j.aogh.2017.09.005 [ubMed]

4. Emani CK, Cullot N, Nicolle C. Understandable big data: A survey. Computer Science Review. 2015; 17: 70-81.

5. Hariri RH, Fredericks EM, Bowers KM. Uncertainty in big data analytics: Survey, opportunities, and challenges. Journal of Big Data. 2019; 6(1): 44.

6. Häyrinen K, Saranto K, Nykänen P. Definition, 
structure, content, use and impacts of electronic health records: A review of the research literature. Int J Med Inform. 2008; 77(5): 291-304. PMID: 17951106 DOI: 10.1016/j.ijmedinf.2007.09.001 [PubMed]

7. Doi K. Computer-aided diagnosis in medical imaging: Historical review, current status and future potential. Comput Med Imaging Graph. 2007; 31(4-5): 198-211. PMID: 17349778 DOI: $\quad$ 10.1016/j.compmedimag.2007.02.002 [PubMed]

8. Big Data Value Association, TF7 Healthcare Subgroup. Big data technologies in healthcare: Needs, opportunities and challenges. BDV publication; 2016.

9. Wang Y, Kung L, Byrd TA. Big data analytics: Understanding its capabilities and potential benefits for healthcare organizations. Technological Forecasting and Social Change. 2018; 126: 3-13.

10. DeMauro A, Greco M, Grimaldi M. What is big data? A consensual definition and a review of key research topics. AIP Conference Proceedings. 2015; 1644(1): 97.

11. Chen M, Mao S, Liu Y. Big data: A survey. Mobile Networks and Applications. 2014; 19(2): 171-209.

12. Murdoch TB, Detsky AS. The inevitable application of big data to health care. JAMA. 2013; 309(13): 1351-2. PMID: 23549579 DOI: 10.1001/jama.2013.393 [PubMed]

13. Bossé É, Roy J, Wark S. Concepts, models, and tools for information fusion. Artech House; 2007.

14. Jin X, Wah BW, Cheng X, Wang Y. Significance and challenges of big data research. Big Data Research. 2015; 2(2): 59-64.

15. Archenaa J, Anita EM. A survey of big data analytics in healthcare and government. Procedia Computer Science. 2015; 50: 408-13.
16. Purkayastha S, Braa J. Big data analytics for developing countries-using the cloud for operational BI in health. The Electronic Journal of Information Systems in Developing Countries. 2013; 59(1): 1-7.

17. Sagiroglu S, Sinanc D. Big data: A review. International Conference on Collaboration Technologies and Systems. IEEE; 2013.

18. Hermon R, Williams PA. Big data in healthcare: What is it used for? Australian eHealth Informatics and Security Conference. Edith Cowan University; 2014.

19. Bossé É, Solaiman B. Information fusion and analytics for big data and IoT. Artech House; 2016.

20. Gunay O, Toreyin BU, Kose K, Cetin AE. Entropyfunctional-based online adaptive decision fusion framework with application to wildfire detection in video. IEEE Trans Image Process. 2012; 21(5): 285365. PMID: 22249709 DOI: 10.1109/TIP.2012.2183141 [PubMed]

21. Pugna IB, Duțescu A, Stănilă OG. Corporate attitudes towards big data and its impact on performance management: A qualitative study. Sustainability. 2019; 11(3): 684 .

22. Minou J, Routsis F, Gallos P, Mantas J. Health informatics scientists' perception about big data technology. Studies in Health Technology and Informatics. 2017; 238: 144-6.

23. Shah N, Irani Z, Sharif AM. Big data in an HR context: Exploring organizational change readiness, employee attitudes and behaviors. Journal of Business Research. 2017; 70: 366-78.

24. Raguseo E. Big data technologies: An empirical investigation on their adoption, benefits and risks for companies. International Journal of Information Management. 2018; 38(1): 187-95. 